\title{
Effects of Weather Factors on Fuel Moisture Contents of Forestland in Chuncheon, South Korea
}

\section{Chae, Hee-mun}

Laboratory of Forest Resources Management, Division of Forest Environmental Sciences, Department of Agro-Environmental Sciences, Faculty of Agriculture, Kyushu University I CDept. of Forest Environment Protection, Kangwon National University

Jeon, Bo-ram

Laboratory of Forest Resources Management, Division of Forest Environmental Sciences, Department of Agro-Environmental Sciences, Faculty of Agriculture, Kyushu University | Dept. of Forest Environment System, Kangwon National University

Lee, Si-Young

Laboratory of Forest Resources Management, Division of Forest Environmental Sciences, Department of Agro-Environmental Sciences, Faculty of Agriculture, Kyushu University I Professional Graduate School of Disaster Prevention, Kangwon National University

Ohga, Shoj i

Laboratory of Forest Resources Management, Division of Forest Environmental Sciences, Department of Agro-Environmental Sciences, Faculty of Agriculture, Kyushu University

https://doi.org/10.5109/1798137

出版情報: 九州大学大学院農学研究院紀要. 62 (1)，pp.23-29，2017-02-24. Faculty of Agriculture， Kyushu University

バージョン :

権利関係 : 


\title{
Effects of Weather Factors on Fuel Moisture Contents of Forestland in Chuncheon, South Korea
}

\author{
Hee-mun Chae', Bo-ram Jeon ${ }^{2}$, Si-Young LEE $^{3}$ and Shoji OHGA* \\ Laboratory of Forest Resources Management, Division of Forest Environmental Sciences, \\ Department of Agro-Environmental Sciences, Faculty of Agriculture, \\ Kyushu University, Fukuoka 811-2415, Japan \\ (Received September 26, 2016 and accepted November 4, 2016)
}

\begin{abstract}
Fuel moisture contents in the forest floor are one of important factors for forest fire spread due to their role as a possible fire ignition and are closely related to changes in weather factors. In the present study, we analyzed changes in forest fuel moisture content for two tree species (Pinus densiflora and Quercus dentata) associated with two different weather measurement data (in-situ measurement within the forest and observation at the weather station) during three consecutive years of monitoring including the Korean forest fire danger seasons (spring and fall). Results showed that the weather data from in-situ measurement within the forest and the CWS (Chuncheon Weather Station) had different patterns in that average temperature and max temperature tended to be higher in the forest, while min temperature had lower in the forest.

These different patterns in weather factors affected the dead forest fuel moisture content thereby causing differences in the forest fuel moisture content among species. Results also revealed significant relation between precipitation and forest fuel moisture content indicating forest fuel moisture content decreases significantly after precipitation events during both seasons. The present study suggests that weather data within the forest which can reflect regional weather characteristics must be acquired to more accurately determine the forest fuel moisture content. Especially in Korea where most of the land consists mainly mountainous forestland. Hence, it is necessary to conduct future research which comprises comparative analysis of various leaf types based on dynamic changes of in-situ weather factors within the forest and monitor precise moisture content changes by leaf type after precipitation in order to ensure the accuracy of forest fire prediction systems during the forest fire danger season.
\end{abstract}

Key words: forest fire, fuel moisture contents, weather factors, fire danger seasons

\section{INTRODUCTION}

Forest fires cause significant social and economic loss as well as ecological damage within the forest ecosystem. Fuel moisture contents in the forest floor are one of important factors for forest fire behavior and intensity due to their role as a possible ignition (Mutch, 1970; Weise et al., 1998; Carlson and Burgan, 2003; Chandler et al., 1983; Van Wagner, 1977). Forest fuel moisture contents are strongly related to fire spread rate and ignition during fire danger seasons. They have been recognized crucial factor for implementing a forest fire danger rating system in many countries (Jack and John, 1985; Stocks et al., 1989; Anderson, 2005; William et al., 2006; Andrew et al., 2009). Much effort has focused on forest fuel moisture contents to determine the probability of forest fire spread and ignition in live and dead fuel in forestland. For example, the forest fire danger rating system, as part of the Fire Weather Index System of Canada

CDept. of Forest Environment Protection, Kangwon National University, Gangwondaehak 1-gil, chuncheon-si, Ganwon-do, Republic of Korea

${ }^{2}$ Dept. of Forest Environment System, Kangwon National University, Gangwondaehak 1-gil, chuncheon-si, Ganwon-do, Republic of Korea

${ }^{3}$ Professional Graduate School of Disaster Prevention, Kangwon National University, Samcheok-Si, Gangwon-Do 245-711, Republic of Korea

* Corresponding Author (E-mail: ohga@forest.kyushu-u.ac.jp) has been developed to link the moisture contents of forest fuel to daily weather condition (Stocks et al., 1989; Lawson and Armitage, 2008). Forest fuel moisture contents are affected by various meteorological factors (temperature, precipitation, humidity, dew, etc.), internal forest fuel factors (specific heat, equilibrium moisture, water diffusion rate), and external forest fuel factors (fuel type and size) (Simard, 1968). Meteorological factors in the forestland are highly related to changes in moisture contents from different types of dead forest fuels thereby indicators of the potential ignition index.

Dead forest fuel include fallen small branches and leaves of coniferous or broadleaf trees, and herbaceous plant on the forest floor (Aguado et al., 2007). The moisture contents of dead fuel are affected by changes in meteorological condition such as temperature, humidity and rainfall. Furthermore, the loss and gain of moisture in the fuel resulting from various atmospheric activities depend on physicochemical and physiological characteristics of the forest fuel (Simard, 1968). Many studies on changes of dead forest fuel moisture contents due to meteorological dynamics were conducted to develop the fire danger rating system by utilizing the Fire Weather Index in Canada and USA, resulting in the development of fuel moisture codes (Van Wagner, 1974; Jack and John, 1985). The Korean fire danger rating system has developed to forecast the daily forest fire possibility by utilizing fuel moisture contents and daily weather observation during the fire danger seasons in the spring (February 
$1^{\text {st }}$ to May $15^{\text {th }}$ ) and in the fall (November $1^{\text {st }}$ to December $\left.15^{\text {th }}\right)$. However, most fire danger rating systems has not reflected changes in actual forest fuel moisture contents in the forest floor because the moisture index for the rating system typically uses meteorological data from the adjacent weather station. Dead forest fuel moisture which affect forest fire ignition and potential are sensitive to meteorological changes (temperature, humidity, wind, rainfall etc.) depending on different forest settings. Moreover, as dead forest fuel generally exists in the surface layer of the forest, understanding the relation between forest fuel moisture content and meteorological factors within the forestland is critical to implement more accurate forest fire prediction system. Therefore, it is important to consider meteorological dynamics based on in-situ observation within the forestland than at the weather stations. In the present study, we investigated meteorological changes within forestland during forest fire danger seasons (spring and fall) and examined effect of weather factors on the change in forest fuel moisture content.

\section{DESCRIPTION AND METHOD}

\subsection{Site description}

The study area is located in the Kangwon National University campus (N $37^{\circ} 52^{\prime} 01.33^{\prime \prime}$, E $127^{\circ} 44^{\prime} 48.15^{\prime \prime}$ ), Chuncheon, Korea. The study site was chosen based on accessibility to the laboratory and relative easiness to collect repetitive dead leaves and similarity of vegetation. The study area has a humid climate characterized

Table 1. General conditions of the study area

\begin{tabular}{|c|c|c|c|c|}
\hline Location & $\begin{array}{c}\text { Average } \\
\text { tree } \\
\text { height } \\
\text { (m) }\end{array}$ & $\begin{array}{l}\text { Average } \\
\text { tree DBH } \\
\quad(\mathrm{cm})\end{array}$ & $\begin{array}{l}\text { Average } \\
\text { crown } \\
\text { width } \\
\text { (m) }\end{array}$ & $\begin{array}{c}\text { Average } \\
\text { clear- } \\
\text { length } \\
\text { (m) }\end{array}$ \\
\hline $\begin{array}{l}\mathrm{N} 37^{\circ} 52^{\prime} 01.33^{\prime \prime} \\
\mathrm{E} 127^{\circ} 44^{\prime} 48.15^{\prime \prime}\end{array}$ & 12 & 22 & 6 & 6 \\
\hline $\begin{array}{l}\text { Slope gradient } \\
\left(^{\circ}\right)\end{array}$ & $\begin{array}{l}\text { Slope } \\
\text { aspect } \\
\left(^{\circ}\right)\end{array}$ & $\begin{array}{c}\text { Litter layer } \\
\text { depth } \\
\text { (cm) }\end{array}$ & $\begin{array}{c}\text { Trees per } \\
\text { ha }\end{array}$ & $\begin{array}{l}\text { Altitude } \\
\text { (m) }\end{array}$ \\
\hline 21 & 250 & 2.5 & 700 & 128 \\
\hline
\end{tabular}

by long, hot summer and long, cold winter. Precipitation falls mainly during summer monsoon period with a 30 year average of $1,347 \mathrm{~mm}$. 30 year average temperature is $11.1^{\circ} \mathrm{C}$ (Chuncheon weather station; $37^{\circ} 53^{\prime} 59.545^{\prime \prime}$ $\mathrm{N}, 127^{\circ} 44^{\prime} 16.387^{\prime \prime} \mathrm{E}$, altitude above sea level $76.82 \mathrm{~m}$ ). The University campus forests consists of mixed coniferous and deciduous stands. Overstory vegetation is Pinus densiflora of similar age with a lesser component of mixed hardwood. Common hardwood species are Quercus dentata and Quercus mongolica. General characteristics of the study area are shown in Table 1 and Figure 1.

\subsection{Experimental methods}

2.2.1 Fuel sampling and fuel moisture content analysis

Fallen Pinus densiflora leaves and Quercus dentata leaves were collected and analyzed to examine the forest fuel moisture content during three consecutive years of the forest fire danger seasons in spring (March 1-May 5, 2013, February 1-May 15, 2014, and February 1-May 15, 2015) and fall (November 1-December 15, 2013, November 1-December 15, 2014, and November 1-December 15, 2015). At the same hour (15:00 pm) each day, we collected three replicates of two leaf types (Pinus densiflora leaves and Quercus dentata leaves) from forest floor in which each sample was $10 \mathrm{~g}$ in weight. The collected leaves was moved to laboratory and left in a dry oven at $105^{\circ} \mathrm{C}$ for 48 hours and weighed again.

Fuel moisture content is expressed as difference in weight between the fuel weight before drying and the fuel weight after drying to the fuel weight after drying (Viney, 1991). To derive fuel moisture content (FMC), the following formula is used (Viegas et al., 1992; Desbois et al., 1997; Aguado et al., 2007):

$$
\operatorname{FMC}(\%)=\left(\mathrm{W}_{\mathrm{w}}-\mathrm{W}_{\mathrm{d}}\right) / \mathrm{W}_{\mathrm{d}} \times 100
$$

Where, $\mathrm{W}_{\mathrm{w}}$ is the fuel weight before drying, and $\mathrm{W}_{\mathrm{d}}$ is the fuel weight after drying.

\subsubsection{Weather data analysis}

To examine the effect of weather factors on forest

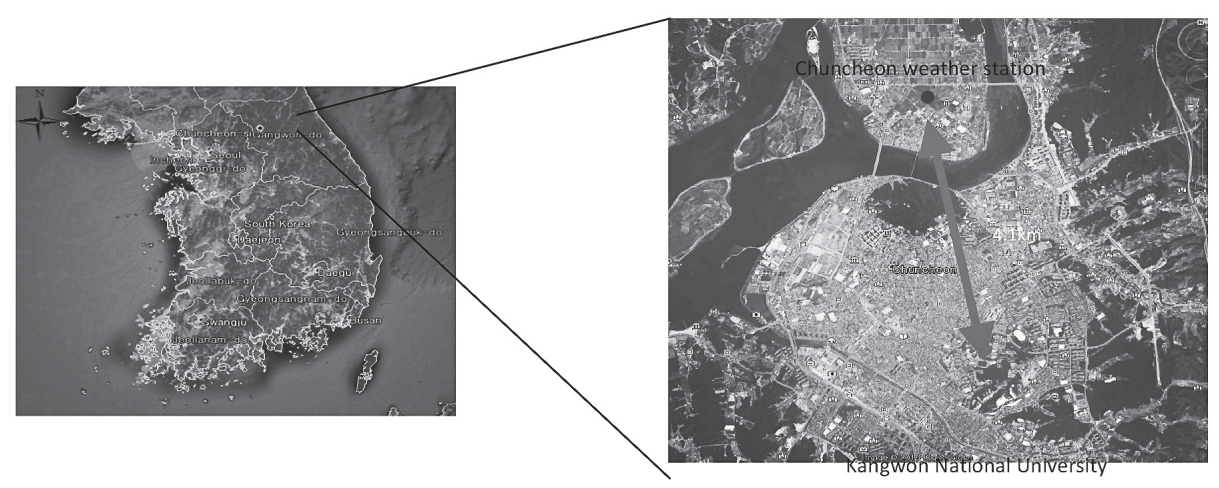

Fig. 1. Location of the study site . 
fuel moisture content, we installed a small instrument shelter in the study area and placed a weather-measuring device (HOBO Data Logger, U12-012) to measure the temperature $\left({ }^{\circ} \mathrm{C}\right)$ and relative humidity (\%) every hour from March $1^{\text {st }}, 2013$ through December $15^{\text {th }}, 2015$. The daily and monthly observation means were calculated for each weather factor measured within the forest, and their relationships with changes in forest fuel moisture content were analyzed. Furthermore, the analyzed weather factors were compared with temperature and humidity data from the same period, as measured by the Chuncheon weather station (Korea Meteorological Administration, 2016). Due to difficulty in rainfall measurement within the forest, the rainfall data from the Chuncheon weather station (CWS) was utilized. These precipitation data were used to examine the changes in the dead fuel moisture content with time (number of days) after precipitation. However, after daily precipitation below $0.5 \mathrm{~mm}$, precipitation did not affect the forest fuel moisture content, thus during the study period, days with below $0.5 \mathrm{~mm}$ of precipitation were excluded. The SPSS (SPSS Statistics ver. 20) statistics program was used to examine the relation between in-situ weather data measured within forestland, the station weather data, and the forest fuel moisture content.

\section{RESULTS AND CONSIDERATION}

\subsection{Comparison of two different weather meas- urements}

We compared difference in weather data between in-situ weather measurements within forestland and the CWS (Table 2). Overall, temperature in the forest was typically higher than the CWS in middle of March and April, but February and May showed little temperature differences during the fall forest fire danger season, the average temperatures in both in-situ weather measurements within forestland and the CWS tended to gradually decrease with time, and the end of November 2014 had lower average temperature than 2013. Unlike the spring forest fire danger season, differences between insitu weather measurements within forestland and the CWS were not significant during the fall season.

During the 2013 spring forest fire danger season, the average temperature in the CWS was $4.7^{\circ} \mathrm{C}$, and $6.4^{\circ} \mathrm{C}$ in the forest, making the forest about $1.9^{\circ} \mathrm{C}$ higher. During the fall forest fire danger season, the average temperature was $2.0^{\circ} \mathrm{C}$ in the CWS and $2.4^{\circ} \mathrm{C}$ in the forest, showing that forest temperature tended to have lower temperature. In 2014, the average temperature in spring was slightly higher in the forest (CWS: $9.2^{\circ} \mathrm{C}$, forest: $9.8^{\circ} \mathrm{C}$ ),

Table 2. Comparison of weather factors between in-situ measurement within forest land and the CWS observation

\begin{tabular}{|c|c|c|c|c|c|c|c|c|c|}
\hline \multirow[b]{2}{*}{ Year } & \multicolumn{5}{|c|}{ CWS } & \multicolumn{4}{|c|}{ Forest land } \\
\hline & month & $\begin{array}{c}\mathrm{T} \\
\left({ }^{\circ} \mathrm{C}\right)\end{array}$ & $\begin{array}{l}\text { MA. T } \\
\left({ }^{\circ} \mathrm{C}\right)\end{array}$ & $\begin{array}{l}\text { MI.T } \\
\left({ }^{\circ} \mathrm{C}\right)\end{array}$ & $\begin{array}{l}\mathrm{RH} \\
(\%)\end{array}$ & $\begin{array}{c}\mathrm{T} \\
\left({ }^{\circ} \mathrm{C}\right)\end{array}$ & $\begin{array}{l}\text { MA. T } \\
\left({ }^{\circ} \mathrm{C}\right)\end{array}$ & $\begin{array}{l}\text { MI.T } \\
\left({ }^{\circ} \mathrm{C}\right)\end{array}$ & $\begin{array}{l}\mathrm{RH} \\
(\%)\end{array}$ \\
\hline \multirow{7}{*}{2013} & 3 & 4.4 & 11.6 & -2.2 & 60.0 & 6.1 & 21.2 & -1.3 & 53.0 \\
\hline & 4 & 4.8 & 12.0 & -2.1 & 58.9 & 6.4 & 21.4 & -1.3 & 52.3 \\
\hline & 5 & 5.0 & 11.9 & -1.7 & 60.5 & 6.6 & 20.7 & -0.9 & 53.5 \\
\hline & mean & 4.7 & 11.8 & -2.0 & 59.8 & 6.4 & 21.1 & -1.2 & 52.9 \\
\hline & 11 & 2.9 & 8.7 & -2.1 & 69.8 & 3.1 & 10.4 & -1.7 & 70.0 \\
\hline & 12 & 1.0 & 6.7 & -2.7 & 86.6 & 1.6 & 7.7 & -2.4 & 84.6 \\
\hline & mean & 2.0 & 7.7 & -2.4 & 78.2 & 2.4 & 9.1 & -2.0 & 77.3 \\
\hline \multirow{8}{*}{2014} & 2 & 0.2 & 6.8 & -4.9 & 64.8 & 0.9 & 14.3 & -5.3 & 63.7 \\
\hline & 3 & 6.8 & 13.5 & 0.3 & 57.3 & 8.1 & 23.6 & 0.7 & 54.2 \\
\hline & 4 & 13.4 & 20.9 & 6.0 & 57.2 & 14.3 & 24.6 & 6.6 & 54.4 \\
\hline & 5 & 16.2 & 23.4 & 10.0 & 59.6 & 16.1 & 24.7 & 9.7 & 63.1 \\
\hline & mean & 9.2 & 16.1 & 2.8 & 59.7 & 9.8 & 21.8 & 2.9 & 58.9 \\
\hline & 11 & 5.3 & 10.6 & 0.5 & 73.1 & 5.2 & 11.3 & 0.2 & 72.8 \\
\hline & 12 & -4.3 & 0.3 & -9.1 & 60.8 & -4.4 & 1.0 & -9.1 & 62.5 \\
\hline & mean & 0.5 & 5.5 & -4.3 & 67.0 & 0.4 & 6.1 & -4.4 & 67.7 \\
\hline \multirow{5}{*}{2015} & 2 & -1.0 & 5.1 & -6.5 & 69.7 & -0.6 & 7.6 & -6.0 & 67.2 \\
\hline & 3 & 5.6 & 13.1 & -1.7 & 50.0 & 6.3 & 18.7 & -1.5 & 46.4 \\
\hline & 4 & 13.2 & 20.3 & 6.3 & 55.2 & 13.6 & 23.2 & 6.4 & 55.6 \\
\hline & 5 & 18.2 & 24.2 & 11.4 & 59.4 & 17.9 & 24.8 & 11.4 & 62.0 \\
\hline & mean & 9.0 & 15.7 & 2.4 & 58.6 & 9.3 & 18.5 & 2.6 & 57.8 \\
\hline
\end{tabular}

$※$. T : Average Temperature, MA.T : Average Max. temperature, MI.T Average Min. temperature, RH : Average Relative Humidity 
and in fall it was slightly lower in the forest (CWS: $0.5^{\circ} \mathrm{C}$, forest: $0.4^{\circ} \mathrm{C}$ ). There were similar trends in the 2015 spring forest fire danger season (CWS: $9.0^{\circ} \mathrm{C}$, forest: $9.3^{\circ} \mathrm{C}$ ).

As for max temperatures, during the 2013, 2014, and 2015 spring forest fire danger seasons, the forest tended to have higher values. In the case of fall season, forest had higher max temperatures than the CWS in both 2013 and 2014. The CWS station had slightly higher min temperatures than the forest in the spring and fall seasons in 2013, however in 2014, there was little temperature difference between the forest and the CWS. In the 2015 spring forest fire danger season, the forest had slightly higher values of min temperature. Overall, the spring season tended to have lower humidity than the fall season. During the spring, the relative humidity in the forest was lower than in the CWS, but there was no difference during the fall forest fire danger season between the two.

During the entire in-situ weather measurement period within the forest, the average temperatures and max temperatures for the spring forest fire danger season had higher than the fall, and min temperatures for the fall season tended to be higher than the spring. Also, the spring season had lower humidity than the fall. These results closely connected to the fact that the occurrence of forest fires has been higher during the Korean spring

Table 3. Relation between fuel moisture contents and precipitation during forest fire danger seasons (spring and fall)

\begin{tabular}{|c|c|c|c|c|}
\hline \multirow{2}{*}{ Year } & \multirow{2}{*}{ Month } & \multicolumn{2}{|c|}{ Fuel moisture contents (\%) } & \multirow{2}{*}{$\begin{array}{c}\mathrm{P} \\
(\mathrm{mm})\end{array}$} \\
\hline & & $\mathrm{PD}$ & $\mathrm{QD}$ & \\
\hline \multirow{7}{*}{2013} & 3 & 29.6 & 29.8 & 24.5 \\
\hline & 4 & 31.1 & 31.0 & 66.6 \\
\hline & 5 & 30.1 & 30.2 & 21.2 \\
\hline & mean & 30.3 & 30.3 & 112.3 \\
\hline & 11 & 26.6 & 28.5 & 27 \\
\hline & 12 & 26.3 & 23.3 & 0 \\
\hline & mean & 26.5 & 25.9 & 27 \\
\hline \multirow{8}{*}{2014} & 2 & 15.9 & 15.7 & 0 \\
\hline & 3 & 13.1 & 11.1 & 4.3 \\
\hline & 4 & 12.0 & 13.0 & 7.5 \\
\hline & 5 & 13.8 & 12.2 & 13.9 \\
\hline & mean & 13.7 & 13.0 & 25.7 \\
\hline & 11 & 21.9 & 18.7 & 28.3 \\
\hline & 12 & 26.8 & 27.9 & 11.1 \\
\hline & mean & 24.4 & 23.3 & 39.4 \\
\hline \multirow{5}{*}{2015} & 2 & 20.9 & 20.3 & 23.1 \\
\hline & 3 & 26.2 & 21.7 & 13.5 \\
\hline & 4 & 21.0 & 22.9 & 22.3 \\
\hline & 5 & 24.2 & 16.4 & 23.4 \\
\hline & mean & 23.1 & 20.3 & 82.3 \\
\hline
\end{tabular}

※. Qd : Quercus dentata Thunb. ex Murray, Pd : Pinus densiflora Siebold \& Zucc., P : Accumulated Precipitation forest fire danger season (average 60\% forest fire occurrence during the last 10 years) than in the fall forest fire danger season (average 10\% forest fire occurrence during the last 10 years) (Korea Forest Service, 2015).

Total precipitation was higher in the spring forest fire danger season $(112.3 \mathrm{~mm})$ than in the fall season (27 mm) of 2013 while in 2014 it was lower in the spring $(25.7 \mathrm{~mm})$ than in the fall $(39.4 \mathrm{~mm})$ (Table 3$)$.

\subsection{Forest fuel moisture content}

The monthly average moisture content of the dead Quercus dentata leaves and the Pinus densiflora leaves (Figs. 2) tended to be lowest in February and highest in December. In the current study, the results was responsible for less precedent moisture condition in forest litter layer resulting from less precipitation fell in February, 2014. Also, the overall monthly average moisture content was higher in the Pinus densiflora leaves than in the Quercus dentata leaves, and this trend was due to physicochemical characteristics in leaves among two tree species. Generally, Pinus densiflora leaves was thin and long with oval shape causing small surface/volume ratio. These differences allow them to adhere easily in the litter layer than Quercus dentata leaves after they fall to the litter, leading to higher moisture content (Scott and Burgan, 2005). Also, Pinus densiflora leaves is decomposed relative slowly than Quercus dentata leaves thereby having higher moisture holding capacity. Among different fire danger seasons, it was found that the fuel moisture content in the fall season (Pinus densiflora, 23.3\%, Quercus dentata 22.4\%) was higher than that of the spring season (Pinus densiflora: 21.4\%, Quercus dentata 20.2\%). However, there existed difference in the fuel moisture content among years. In 2013, the moisture content of both leaf types was higher in the spring season than in the fall season while in 2014 the fall season had higher than the spring. It is believed that this trend is closely related to the amount of precipitation. In 2013, the spring had more precipitation than the fall while in 2014, the fall season had more precipitation than the spring (Table 3).

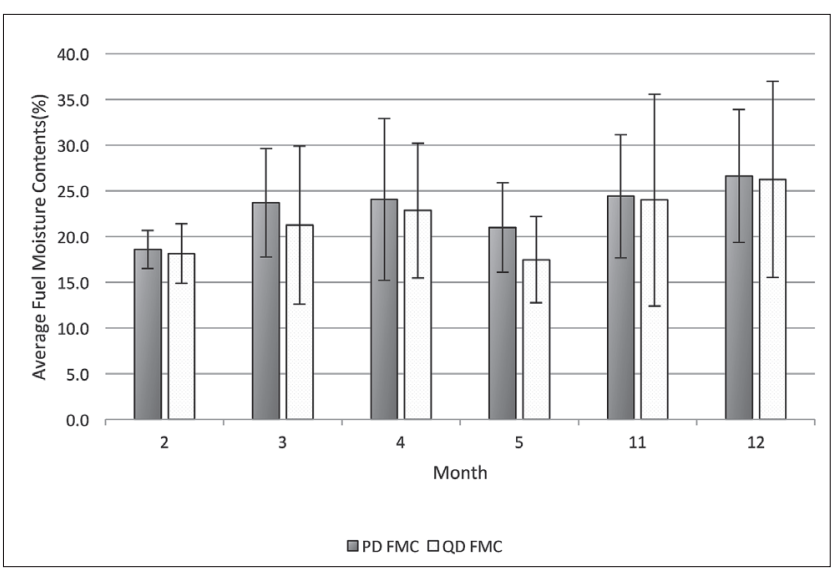

Fig. 2. Change in average fuel moisture contents of two species leaves during three consecutives years. (QD FMC: Quercus dentata Thunb. ex Murray Fuel Moisture Contents. PDFMC: Pinus densiflora Siebold \& Zucc. Fuel Moisture Contents.) 


\subsection{Relation between forest fuel moisture content and weather factors}

We examined the relation between forest fuel moisture content and various weather factors measured in both the forest and the CWS as shown in Table 4.

We found significant relations between weather data and forest fuel moisture content. In the case of the Pinus densiflora leaf, max temperature, relative humidity, and daily precipitation observed in the CWS showed significant relationship with the dead leaf moisture content while max temperature and relative humidity measured within the forest showed significant relation. Also, average temperature, relative humidity, and daily precipitation observed in the CWS had significant relation with the dead leaf moisture content of Quercus dentata while average temperature, max temperature, and relative humidity measured within the forest were closely related to the dead leaf moisture content of Quercus dentata.

We also examined the seasonal relation between weather factors measured in both the forest and the CWS and the dead leaf moisture content (Table 5). In the case of the CWS observation during the spring forest fire danger season, the dead leaf moisture content of Pinus densiflora was closely correlated with relative humidity and precipitation, while for Quercus dentata, the dead leaf moisture content was related to max temperature, relative humidity and precipitation. During the fall forest fire danger season, the moisture content in both leaf types did not show significant correlation with weather factors observed in the CWS, however two weather factors such as relative humidity and max temperature measured within the forest were significant with the dead fuel moisture content. These results showed

Table 4. Relation between forest fuel moisture contents and weather data with different weather measurements

\begin{tabular}{|c|c|c|c|c|c|c|c|c|c|c|}
\hline \multirow[b]{2}{*}{ Species } & \multirow{2}{*}{$\begin{array}{l}\text { Coefficient } \\
\text { of } \\
\text { correlation }\end{array}$} & \multicolumn{5}{|c|}{ CWS } & \multicolumn{4}{|c|}{ Forest land } \\
\hline & & $\begin{array}{c}\mathrm{T} \\
\left({ }^{\circ} \mathrm{C}\right)\end{array}$ & $\begin{array}{l}\text { MA. T } \\
\left({ }^{\circ} \mathrm{C}\right)\end{array}$ & $\begin{array}{l}\text { MI.T } \\
\left({ }^{\circ} \mathrm{C}\right)\end{array}$ & $\begin{array}{l}\mathrm{RH} \\
(\%)\end{array}$ & $\begin{array}{c}\mathrm{P} \\
(\mathrm{mm})\end{array}$ & $\begin{array}{c}\mathrm{T} \\
\left({ }^{\circ} \mathrm{C}\right)\end{array}$ & $\begin{array}{l}\text { MA. T } \\
\left({ }^{\circ} \mathrm{C}\right)\end{array}$ & $\begin{array}{l}\text { MI.T } \\
\left({ }^{\circ} \mathrm{C}\right)\end{array}$ & $\begin{array}{l}\mathrm{RH} \\
(\%)\end{array}$ \\
\hline \multirow[t]{2}{*}{$\mathrm{PD}$} & $\begin{array}{c}\text { Pearson } \\
\text { coefficient }\end{array}$ & -.074 & $-.153^{*}$ & -.006 & $.161^{* *}$ & $.443^{* *}$ & -.087 & $-.172 * *$ & -.024 & $.215^{* *}$ \\
\hline & $\mathrm{P}$ & .232 & .013 & .920 & .009 & .000 & .163 & .005 & .699 & .000 \\
\hline \multirow{2}{*}{$\mathrm{QD}$} & $\begin{array}{c}\text { Pearson } \\
\text { coefficient }\end{array}$ & $-.149 *$ & $-.227 * *$ & -.078 & $.168^{* *}$ & $.379 * *$ & $-.163^{* *}$ & $-.231 * *$ & -.100 & $.231^{* *}$ \\
\hline & $\mathrm{P}$ & .016 & .000 & .207 & .007 & .000 & .008 & .000 & .105 & .000 \\
\hline
\end{tabular}

* The correlation coefficient is significant at the 0.05 level

** The correlation coefficient is significant at the 0.01 level

※. QD : Quercus dentata Thunb. ex Murray, PD : Pinus densiflora Siebold \& Zucc. T : Average Temperature, MA.T : Average Max. temperature, MI.T Average Min. temperature, RH : Average Relative Humidity, P : Accumulated Precipitation

Table 5. Relation between forest fuel moisture contents and weather data with different weather measurements by forest fire season

\begin{tabular}{|c|c|c|c|c|c|c|c|c|c|c|c|}
\hline \multirow{2}{*}{$\begin{array}{c}\text { Fire } \\
\text { danger } \\
\text { seasons }\end{array}$} & \multirow[b]{2}{*}{ Species } & \multirow{2}{*}{$\begin{array}{l}\text { Coefficient } \\
\text { of } \\
\text { correlation }\end{array}$} & \multicolumn{5}{|c|}{ CWS } & \multicolumn{4}{|c|}{ Forest land } \\
\hline & & & $\begin{array}{c}\mathrm{T} \\
\left({ }^{\circ} \mathrm{C}\right)\end{array}$ & $\begin{array}{l}\text { MA. T } \\
\left({ }^{\circ} \mathrm{C}\right)\end{array}$ & $\begin{array}{l}\text { MI.T } \\
\left({ }^{\circ} \mathrm{C}\right)\end{array}$ & $\begin{array}{l}\mathrm{RH} \\
(\%)\end{array}$ & $\begin{array}{c}\mathrm{P} \\
(\mathrm{mm})\end{array}$ & $\begin{array}{c}\mathrm{T} \\
\left({ }^{\circ} \mathrm{C}\right)\end{array}$ & $\begin{array}{l}\text { MA. T } \\
\left({ }^{\circ} \mathrm{C}\right)\end{array}$ & $\begin{array}{l}\text { MI.T } \\
\left({ }^{\circ} \mathrm{C}\right)\end{array}$ & $\begin{array}{l}\mathrm{RH} \\
(\%)\end{array}$ \\
\hline \multirow{4}{*}{ Spring } & \multirow[t]{2}{*}{$\mathrm{PD}$} & $\begin{array}{c}\text { Pearson } \\
\text { coefficient }\end{array}$ & -.062 & -.128 & .000 & $.186^{* *}$ & $.527 * *$ & -.068 & $-.145^{*}$ & -.016 & $.179 *$ \\
\hline & & $\mathrm{P}$ & .381 & .071 & .997 & .008 & .000 & .340 & .041 & .824 & .011 \\
\hline & \multirow[t]{2}{*}{$\mathrm{QD}$} & $\begin{array}{c}\text { Pearson } \\
\text { coefficient }\end{array}$ & $-.145^{*}$ & $-.214^{* *}$ & -.068 & $.252^{* *}$ & $.474 * *$ & $-.152 *$ & $-.211^{* *}$ & -.092 & $.232^{* *}$ \\
\hline & & $\mathrm{P}$ & .040 & .002 & .336 & .000 & .000 & .032 & .003 & .193 & .001 \\
\hline \multirow{4}{*}{ Fall } & \multirow[t]{2}{*}{$\mathrm{PD}$} & $\begin{array}{c}\text { Pearson } \\
\text { coefficient }\end{array}$ & .044 & -.138 & .119 & .022 & .164 & .007 & -.191 & .096 & $.255^{*}$ \\
\hline & & $\mathrm{P}$ & .734 & .289 & .359 & .869 & .205 & .957 & .141 & .463 & .048 \\
\hline & \multirow[t]{2}{*}{$\mathrm{QD}$} & $\begin{array}{c}\text { Pearson } \\
\text { coefficient }\end{array}$ & -.061 & -.217 & .000 & -.050 & .212 & -.096 & $-.268^{*}$ & -.022 & .169 \\
\hline & & $\mathrm{P}$ & .638 & .093 & .998 & .702 & .101 & .462 & .037 & .868 & .193 \\
\hline
\end{tabular}

* The correlation coefficient is significant at the 0.05 level

** The correlation coefficient is significant at the 0.01 level

※. QD : Quercus dentata Thunb. ex Murray, PD : Pinus densiflora Siebold \& Zucc. T : Average Temperature, MA.T : Average Max. temperature, MI.T : Average Min. temperature, RH : Average Relative Humidity, P : Accumulated Precipitation 
that forest micrometeorological factors are critical for accurate measurement of forest fuel moisture content. Essentially, forest microclimate measurements can be used as a basis for more accurately predicting forest fuel moisture content.

As for the weather data measured within the forest, the dead leaf moisture content of Pinus densiflora was correlated with max temperature and relative humidity during the spring season, while the dead leaf moisture content of Quercus dentata was highly correlated with average temperature, max temperature and relative humidity. In the fall season, the dead leaf moisture content of Pinus densiflora had significant relation with the relative humidity and the dead leaf moisture content of Quercus dentata was highly correlated with max temperature. These results showed that more weather factors had significant relation in the spring season than in the fall season, indicating that weather data during spring were more sensitive to change in forest fuel moisture content. However, the fall measurement period was shorter than in the spring, caution should be excised to better understand these trends. Especially, during the spring forest fire danger season, the dead leaf moisture content of Quercus dentata showed significant relation with weather factors measured in both the forest and the CWS, representing the dead leaf moisture content of Quercus dentata had more close relation to changes of the forest fuel moisture content resulting from weather factors than that of Pinus densiflora. This result was responsible for different physical characteristics of the leaves as they had different surface/ volume ratio and the fallen leaf position in the forest floor, etc.).

\subsection{Changes in forest fuel moisture content after precipitation}

Precipitation is one of major factors affecting changes in moisture content of the forest litter layer and it has been shown that rainfall intensity and rainfall frequency were closely related to the forest fuel moisture content (Sérgio et al., 2014). The results showed that after average daily precipitation of $9.2 \mathrm{~mm}$, Pinus densiflora (49.3\%) had less average dead leaf moisture content than that of Quercus dentata (53.3\%), and 3 days after precipitation both dead leaf moisture contents drastically fell to below 20\% (Table 6). Figure 3 shows changes in the forest fuel moisture content after daily precipitation event of $19 \mathrm{~mm}$. During the precipitation event, the dead leaf moisture content was $87.4 \%$ (Quercus dentata) and $62.7 \%$ (Pinus densiflora), respectively. However 2 days after precipitation, it drastically fell to $13.3 \%$ for (Quercus dentata) and 17\% (Pinus densiflora). The rate of reduction in the dead leaf moisture content was higher for Quercus dentata than for Pinus densiflora. This result is responsible for differences in physicochemical and physiological characteristics between the two leaves (Simard, 1968).

\section{CONCLUSION}

The present study examined changes in forest fuel moisture content for two tree species (Quercus dentata leaves and Pinus densiflora leaves) associated with two different weather measurements during three consecutive years including the Korean forest fire danger seasons. The weather data from in-situ measurement within the forest and the CWS had different patterns in that average temperature and max temperature tended to be higher in the forest, while min temperature had lower in the forest. These different patterns affected the dead forest fuel moisture content thereby causing differences in the forest fuel moisture content among species. Changes in weather factors after precipitation (daily average temperature, hourly temperature changes, accumulated rainfall, rainfall intensity, etc.) can have various effects on forest fuel moisture content. The present study revealed significant relation between precipitation and forest fuel moisture content indicating forest fuel moisture content decreases significantly after precipitation events during both seasons. Hence, it is necessary to conduct future research which comprise comparative analysis of various

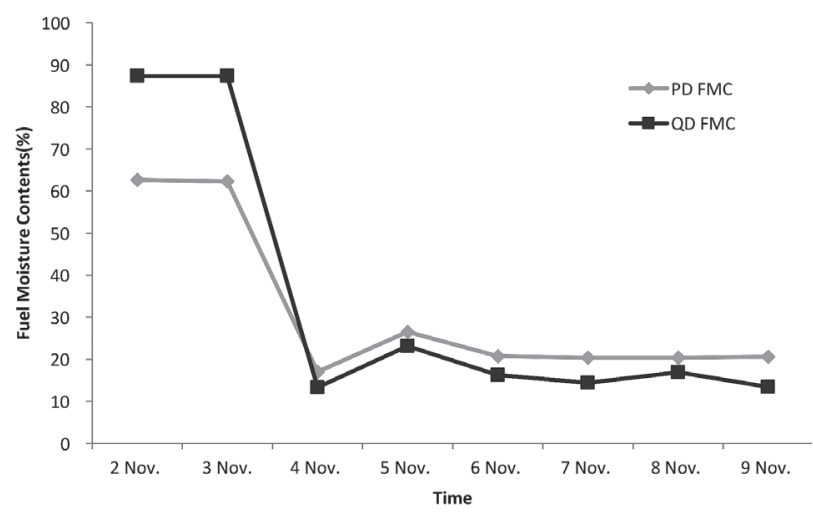

Fig. 3. Change in fuel moisture contents after precipitation event during the fall forest fire danger seasons.

Table 6. Change in fuel moisture content of two species leaves with time after precipitation

\begin{tabular}{|c|c|c|c|c|c|c|c|c|c|c|c|}
\hline \multicolumn{2}{|c|}{$\begin{array}{c}\text { Days after } \\
\text { precipitation }\end{array}$} & 1 & 2 & 3 & 4 & 5 & 6 & 7 & 8 & 9 & 10 \\
\hline \multirow{2}{*}{ FMC (\%) } & $\mathrm{PD}$ & 49.3 & 28.9 & 23.4 & 20.9 & 17.8 & 17.6 & 16.6 & 19.5 & 16.9 & 16.4 \\
\hline & QD & 52.3 & 30.6 & 21.3 & 20.7 & 19.4 & 15.7 & 14.4 & 16.7 & 11.9 & 11.0 \\
\hline
\end{tabular}

※. Qd: Quercus dentata Thunb. ex Murray, PD: Pinus densiflora Siebold \& Zucc. FMC: Fuel Moisture Contents. 
leaf types based on dynamic changes in weather factors and monitor precise moisture content changes by leaf type after precipitation in order to ensure the accuracy of forest fire prediction systems during the forest fire danger season. The present study suggests that weather data within the forest which can reflect regional weather characteristics must be acquired to more accurately determine the forest fuel moisture content. Especially in Korea where most of the land consists mainly mountainous forestland, it is important to acquire in-situ measurement data within the forest settings. Understanding forest fuel moisture content is crucial for implementing the forest fire climate index as part of creating regional forest fire prediction system. Because forest moisture content closely reflects the regional weather characteristics, it should consider change in forest weather factors resulting from the physical environment (slope, altitude, gradient, etc.) surrounding the forest and forest stand characteristics (tree types, tree density, tree age, etc.). As such, our results can be used as basic data to predict regional forest fuel moisture content, and to develop more structural and systematic techniques for understanding relationship between forest weather factors and forest fuel moisture content in order to create regional forest fire prediction system.

Acknowledgement: This study was supported by 2012 Research Grant from Kangwon National University

\section{REFERENCES}

Aguado, I., E. Chuvieco, R. Boren and H. Nieto 2007 Estimation of dead fuel moisture content from meteorological data in Mediterranean area. Applications in fire danger assessment. International Journal of Wildland Fire 16: 390-397

Anderson, S. 2005 Forest and Rural Fire Danger Rating In New Zealand. Forest and Rural Fire Danger Rating in New Zealand. In: Colley, M(ed). Forest Handbook. New Zealand Institute of Forestry, Christchurch. pp. 241-244

Andrew, J. D., A. M. Graham, F. Klara and G. William de 2009 Australian fire weather as represented by the McArthur Forest Fire Danger Index and the Canadian Forest Fire Weather Index. Centre for Australian Weather and Climate Research, Bushfire Cooperative Research Centre, Canadian Forest Service, CAWCR Technical Report No. 10. p. 84

Carlson, J. D. and R. E. Burgan 2003 The review of user's need in operational fire danger estimation: the Oklahoma example. International Journal of Remote Sensing 24: 1601-1620

Chandler, C., P. Cheney, P. Thomas, L. Trabaud and D. Williams 1983 Fire in Forestry. Forest Fire behavior and effects. Nueva York. John Wiley and Sons

Desbois, N., M. Deshayes and A. Beudoin 1997 Protocol for fuel moisture contents measurements. In : A review of remote sensing methods for the study a large wildland fires edited by $\mathrm{E}$.
Chuvieco. Universidae de Alacala, Alcala de Henares 61-72 Jack, D. C. and E. D. John 1985 The National Fire-Danger Rating System: basic equations. United States Department of Agriculture Forest Service, Pacific Southwest Rating System: Forest and Range Experiment Station General Technical Report PSW-82. p. 16

Korea Forest Service 20152014 Statistical Yearbook of Forest Fire. p. 216 (in Korea)

Korea Meteorological Administration 2016 http://www.kma.go.kr/ (in Korea)

Lawson, B. D. and O. B. Armitage 2008 Weather Guide for the Canadian Forest Fire Danger Rating System. Canadian Forest Service Northern Forestry Centre. For an electronic version of this report, visit the Canadian Forest Service Bookstore at http://bookstore.cfs.nrcan.gc.ca/. p. 73

Mutch, R. W. 1970 Wildland fire and ecosystem - a hypothesis. Ecology 51: 1046-1051

Simard, A. J. 1968 The moisture of forest fuels -I. A review of the basic concepts. Forest Fire Research Institute. Department of Forestry and Rural Development. Information Report FF-X-14. p. 47

Scott, J. H. and R. E. Burgan 2005 Standard Fire Behavior Fuel Models: A Comprehensive Set for Use with Rothermel's Surface Fire Spread Model. General Technical Report RMRS-GTR153. Fort Collins, CO: U.S. Department of Agriculture, Forest Service, Rocky Mountain Research Station. p. 72

Sérgio, L., X. V. Domingos, L. Luís de and T. V. Maria 2014 Rainfall effects on fine forest fuels moisture content. In book: Advances in Forest Fire Research, Chapter: Fire Risk Assessment and Climate Change, Imprensa da Universidade de Coimbra, pp. 1256-1263 DOI: 10.14195/978-989-26-0884$6 \_137$

Stock, B. J., B. D. Lawson, M. E. Alexander, C. E. Van Wagner, R. S McApline, T. J. Lynham and D. E. Dubé 1989 Canadian forest fire danger rating system: an overview. Forestry Chronicle 65: $258-265$

Van Wagner, C. E. 1974 Structure of the Canadian Forest Fire Weather Index. Department of the Environment, Canadian Forestry Service publication No. 1333 Ottawa. p. 44

Van Wagner, C. E. 1977 Conditions for the start and spread of crown fire. Canadian Journal of Forest Fire Research $\mathbf{7}$ $23-34$

Viegas, D. X., T. P. Viegas and A. D. Ferreira 1992 Moisture contents of fine forest fuels and fire occurrence in central Portugal. International Journal of Wildland Fire 2: 69-85

Viney, N. R. 1991 A review of fine fuel moisture modeling. International Journal of Wildland Fire 1: 215-234

Weise, D. R., R. A. Hartford and L. Mahaffey 1998 Assessing live fuel moisture for fire management applications. In Processing $20^{\text {th }}$ Tall Timber Fire Ecology Conference: Fire in Ecosystem Management: Shifting the Paradigm from Suppression to Prescription. 7-10 May 1996. Boise, ID. (Eds TR Pruden, LA Brennan) Timbrts Research Station, Proceeding FC20, pp. 49-55. at http://www.fs.fed.us/psw/publications/weise/ psw_1998_weise000.pdf

William, J. de G., D. F. Robert, A. B. Michael, R. Orbita and M. Maznorizan 2006 Development of the Indonesian and Malaysian Fire Danger Rating Systems. Mitig Adapt Strat Glob Change 12: 165-180 